\title{
RP-LC and HPTLC Methods for the \\ Determination of Olmesartan Medoxomil and Hydrochlorothiazide in Combined Tablet Dosage Forms
}

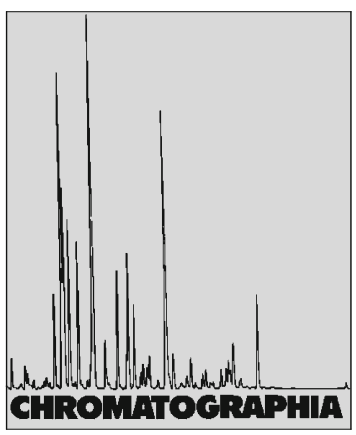

2009, 69, 1469-1472

\author{
P. D. Bari, A. R. Rote ${ }^{\square}$
}

Department of Pharmaceutical Chemistry, MGV's Pharmacy College Panchavati, New Mumbai Agra Road, Nashik, Maharashtra 422003, India; E-Mail: ambrote@rediffmail.com

\begin{abstract}
Two new, rapid, precise, accurate and specific chromatographic methods were described for the simultaneous determination of olmesartan medoxomil and hydrochlorothiazide in combined tablet dosage forms. The first method was based on reversed phase liquid chromatography using an Eurosphere $100 \mathrm{RPC} 18$ column $(250 \times 4.6 \mathrm{~mm}$ ID, $5 \mu \mathrm{m})$. The mobile phase was methanol-0.05\% o-phosphoric acid $(60: 40 \mathrm{v} / \mathrm{v})$ at a flow rate of $1.0 \mathrm{~mL} \mathrm{~min}{ }^{-1}$. Commercially available tablets and laboratory mixtures containing both drugs were assayed and detected using a UV detector at $270 \mathrm{~nm}$. The second method involved silica gel $60 \mathrm{~F}_{254}$ high performance thin layer chromatography and densitometric detection at $254 \mathrm{~nm}$ using acetonitrile-ethyl acetate-glacial acid $(7: 3: 0.4 \mathrm{v} / \mathrm{v} / \mathrm{v})$ as the mobile phase. Calibration curves ranged between 200-600 and 125-375 $\mathrm{ng} \mathrm{spot}^{-1}$ for olmesartan and hydrochlorothiazide, respectively.
\end{abstract}

\section{Keywords}

Column liquid chromatography

High performance thin layer chromatography

Hydrochlorothiazide

Olmesartan medoxomil

\section{Introduction}

Olmesartan medoxomil (OLM) is a prodrug and hydrolyzed to olmesartan during absorption from the gastrointestinal tract [1-4]. OML is a selective AT1 sub- type angiotensin II receptor antagonist. OLM is described chemically as the (5-methyl-2-oxo-1,3-dioxol-4-yl) methyl ester of 4-(1-hydroxy-1-methylethyl) -2-propyl-1-\{[2'-(1H-tetrazol-5-yl)[1,1'biphenyl]-4-yl]methyl $\}-1 H$-imidazole-5- carboxylic acid [5, 6]. Hydrochlorothiazide (HCT), 6-chloro-3,4-dihydro-2 $\mathrm{H}$ 1,2,4-benzothiadiazine-7-sulphonamide 1,1-dioxide, one of the oldest and widely used thiazide diuretics [7] (Fig. 1).

OLM has not yet been officially described in any pharmacopoeia. A literature survey revealed that several analytical methods were reported for the determination of OML in biological fluids including liquid chromatography tandem mass spectrometry (LC-MSMS), capillary electrophoresis (CE), LC and high performance thin layer chromatography (HPTLC) [8-13]. OLM determination has been reported for single preparations or in combination with other antihypertensive drugs [14, 15]. The USP describes an RP-HPLC method for the determination of HCT in tablets. Several analytical methods have been reported for the determination of HCT in pharmaceutical formulations including polarography, LC, HPTLC, and spectrofluorometry [1626]. A literature survey revealed that analytical methods have not been reported for the determination of OML and HCT in a combined tablet formulation. The present study was therefore aimed to provide such an economically viable RP-LC and HPTLC method.
Full Short Communication DOI: $10.1365 /$ s10337-009-1094-Z 0009-5893/09/06
Chromatographia 2009, 69, June (No. 11/12) (C) 2009 The Author(s).

This article is published with open access at Springerlink.com 


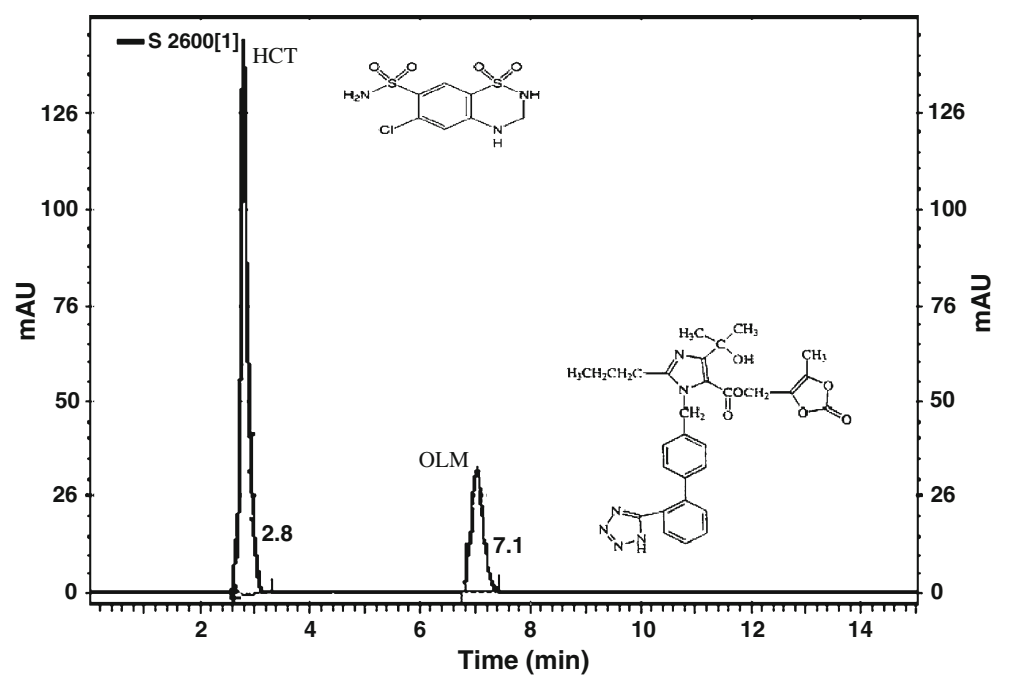

Fig. 1. Representative HPLC chromatogram and structures of olmesartan medoxomil OLM $\left(20 \mu \mathrm{g} \mathrm{mL}^{-1}\right)$ and hydrochlorothiazide HCT $\left(12.5 \mu \mathrm{g} \mathrm{mL}^{-1}\right)$

\section{Experimental}

\section{Apparatus}

The HPLC system consisted of a LC Knauer pump smartline 1000 and a Knauer manual injector using a $20 \mu \mathrm{L}$ fixed loop. A UV/VIS detector was set at $270.0 \mathrm{~nm}$ and peak areas were integrated automatically using Chromgate software. Samples were applied as $8 \mathrm{~mm}$ bands by means of a Camag Linomat V automatic sample applicator (Muttenz Switzerland) equipped with a $100 \mu \mathrm{L}$ syringe. The distance between the bands was $11.4 \mathrm{~mm}$. Silica gel $60 \quad \mathrm{~F}_{254}$ HPTLC plates $(20 \times 10 \mathrm{~cm}$, aluminum $)$ were from Merck (Darmstadt, Germany). Densitometric scanning was performed at $254 \mathrm{~nm}$ with a Camag TLC scanner 3 equipped with Camag Wincats software 1.4.2 using the deuterium light source and slit dimensions of $6.00 \mathrm{~mm} \times 0.45 \mathrm{~mm}$.

\section{Chemicals}

Olmesartan medoxomil (OML) and hydrochlorothiazide (HCT) were kindly supplied by Ajanta Pharmaceutical Pvt. (Paithan) and Glen Mark Pharma (Nashik). All chemicals were of HPLC grade, methanol and acetonitrile ( $\mathrm{S} \mathrm{d}$ fine-chem, Mumbai, India), water and ethyl acetate (Merck, Mumbai, India), $o$-phosphoric acid (Qualigens, Mumbai, India). Commercially available tablets
(Olmesar-H of Macleod, Gujarat, India), containing $20 \mathrm{mg} \mathrm{OML}$ and $12.5 \mathrm{mg}$ HCT per tablet, $12.5 \mathrm{mg}$ tablet ${ }^{-1}$ ) were used for analysis.

\section{Stock Solutions of Standard OLM and HCT for RP-LC and HPTLC}

OLM and HCT stock solutions (1.0 $\mathrm{mg} \mathrm{mL}^{-1}$ ) were prepared in methanol. The standard working concentrations of mixed OLM $\left(20 \mu \mathrm{g} \mathrm{mL}^{-1}\right)$ and HCT $\left(12.5 \mu \mathrm{g} \mathrm{mL}^{-1}\right)$ were prepared in the mobile phase using methanol- $0.05 \%$ $o$-phosphoric acid $(60: 40 \quad v / v)$. This solution was subjected to LC analysis. A $10 \mathrm{~mL}$ standard working solution containing $200 \mathrm{ng}$ OML and $125 \mathrm{ng}$ HCT was spotted on the TLC plate.

\section{Reversed Phase High Performance Liquid Chromatography}

\section{Chromatographic Conditions}

Solutions and mobile phases were freshly prepared prior to use. The mobile phase consisted of methanol- $0.05 \%$ o-phosphoric acid $(60: 40 v / v)$. The analytical column was an Eurosphere $100 \mathrm{C} 18$ column $(250 \times 4.6 \mathrm{~mm}$, Knauer, Berlin, Germany). UV detection was carried out at $270 \mathrm{~nm}$. Analyses were performed under isocratic conditions at a flow-rate of $1.0 \mathrm{~mL} \mathrm{~min}{ }^{-1}$. All solvents were filtered through $0.45 \mu \mathrm{m}$ membrane filters and degassed in an ultrasonic bath.

\section{Calibration}

For calibration purposes, a range of 4 $24 \mu \mathrm{g} \mathrm{mL}^{-1} \mathrm{OLM}$ and $2.5-15 \mu \mathrm{g} \mathrm{mL}^{-1}$ HCT solutions were prepared and $20 \mu \mathrm{L}$ injections were carried out in triplicate. OLM and HCT sample concentrations were calculated based on calibration curves. System suitability tests were also carried out.

\section{Analysis of Tablet Formulations}

Ten tablets were weighed accurately and powdered. Powder equivalent to $100 \mathrm{mg}$ OLM and $62.5 \mathrm{mg}$ HCT was weighed and transferred to a $100 \mathrm{~mL}$ volumetric flask. It was dissolved in $50 \mathrm{~mL}$ methanol by shaking the flask for $15 \mathrm{~min}$ and filled to volume with methanol, followed by filtration through a $0.45 \mu \mathrm{m}$ membrane filter. A final concentration of $20 \mu \mathrm{g} \mathrm{mL}^{-1}$ of OLM and $12.5 \mu \mathrm{g} \mathrm{mL}^{-1}$ of HCT were prepared and concentrations of the OLM and HCT were calculated from the calibration graph.

\section{Recovery Study}

The accuracy of the proposed method was evaluated by the addition of a standard drug solution to a pre-analysed tablet sample solution at three different concentration levels at 80, 100 and $120 \%$ of linearity for both drugs.

\section{High Performance Thin Layer Chromatography}

\section{Chromatographic Conditions}

Chromatography was performed on $20 \mathrm{~cm} \times 10 \mathrm{~cm}$ aluminum HPTLC plates coated with $0.2 \mathrm{~mm}$ layers of silica gel $60 \mathrm{~F}_{254}$ (Merck). Before use plates were washed with methanol and dried in an oven at $120^{\circ} \mathrm{C}$ for $20 \mathrm{~min}$. Ascending development of the plate with a migration distance of $70 \mathrm{~mm}$ was performed at $23 \pm 2{ }^{\circ} \mathrm{C}$ using acetonitrile-ethyl acetate-glacial acid $(7: 3: 0.4, v / v / v)$ as the mobile phase and a Camag twin-trough 
Table 1. Calibration graphs and system suitability $(n=5)$ of olmesartan medoxomil and hydrochlorothiazide by RP-LC and HPTLC

\begin{tabular}{|c|c|c|c|c|}
\hline \multirow[t]{2}{*}{ Parameter } & \multicolumn{2}{|l|}{ RP-LC } & \multicolumn{2}{|l|}{ HPTLC } \\
\hline & OLM & HCT & OLM & HCT \\
\hline Linearity range & $4-24 \mu \mathrm{g} \mathrm{mL}^{-1}$ & $2.5-15 \mu \mathrm{g} \mathrm{mL}^{-1}$ & $200-600 \mathrm{ng} \mathrm{spot}^{-1}$ & $125-375 \mathrm{ng} \mathrm{spot}^{-1}$ \\
\hline \multicolumn{5}{|l|}{ Regression equation } \\
\hline Slope & 24,055 & 104,515 & 8.79 & 9.18 \\
\hline Intercept & 688.3 & $-1,915.7$ & 184.12 & 441.13 \\
\hline Coefficient of correlation & 0.9998 & 0.9999 & 0.9992 & 0.994 \\
\hline Limit of detection (LOD) & $0.44 \mu \mathrm{g} \mathrm{mL}^{-1}$ & $0.21 \mu \mathrm{g} \mathrm{mL}^{-1}$ & $20.20 \mathrm{ng} \mathrm{spot}^{-1}$ & $18.65 \mathrm{ng} \mathrm{spot}^{-1}$ \\
\hline Limit of quantitation (LOQ) & $1.32 \mu \mathrm{g} \mathrm{mL}^{-1}$ & $0.63 \mu \mathrm{g} \mathrm{mL}^{-1}$ & $61.07 \mathrm{ng} \mathrm{spot}^{-1}$ & $57.24 \mathrm{ng} \mathrm{spot}^{-1}$ \\
\hline \multicolumn{5}{|l|}{ System suitability } \\
\hline Åsymmetry & 1.75 & 1.22 & - & - \\
\hline No. of theoretical plates & 2,313 & 4,976 & - & - \\
\hline Capacity factor & 12.8 & 34.33 & - & - \\
\hline
\end{tabular}

chamber previously saturated with mobile phase for $20 \mathrm{~min}$. The average development time was $20 \mathrm{~min}$.

\section{Calibration}

Mixed working standard solutions equivalent to $20,30,40,50,60 \mu \mathrm{L}$ were separately spotted on the TLC plate in order to obtain final OML concentrations at 200, 300, 400, 500, $600 \mathrm{ng} \mathrm{spot}^{-1}$ and HCT at 125, 187.5, 250, 312.5, $375 \mathrm{ng}$ spot $^{-1}$, respectively. The plates were developed in a $20 \times 10 \mathrm{~cm}$ twin through chamber using $20 \mathrm{~mL}$ freshly prepared mobile phase.

\section{Analysis of Tablet Formulation}

Ten tablets were weighed, triturated and the average tablet weight was calculated. A $1.0 \mathrm{mg} \mathrm{mL}^{-1}$ solution was prepared in methanol and filtered through Whatman filter paper no. 41. Five mL tablet stock solution were diluted to $50 \mathrm{~mL}$ with methanol which was used as the working standard solution. This solution was spotted $(5 \mu \mathrm{L})$ on the HPTLC plate to give a concentration of $500 \mathrm{ng} \mathrm{spot}^{-1}$ of OLM equivalent to $312.5 \mathrm{ng}$ spot $^{-1}$ of HCT. Both concentrations were calculated from the calibration graph.

\section{Recovery Study}

The accuracy of the proposed method was evaluated by the addition of a standard drug solution to a pre-analysed tablet sample solution at three different concentration levels at 80, 100 and $120 \%$ of linearity for both drugs.

\section{Results and Discussion}

\section{Reversed Phase High \\ Performance Liquid Chromatography}

A satisfactory separation was obtained when using methanol-0.05\% o-phosphoric acid $(60: 40 \mathrm{v} / \mathrm{v})$ under isocratic conditions and a flow rate of

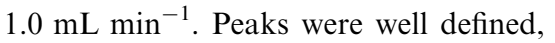
resolved and almost free from tailing. Retention times for OLM and HCT were observed at $2.8 \mathrm{~min}$ and $7.1 \mathrm{~min}$, respectively (Fig. 1) and the optimum wavelength was determined to be $270.0 \mathrm{~nm}$.

System suitability tests were also carried out to verify reproducibility and results are summarised in Table 1. For quantitative applications linear calibration graphs were obtained with correlation coefficients of 0.9998 and 0.9999 for OLM and HCT, respectively. Limits of detection (LOD) were $0.44 \mu \mathrm{g} \mathrm{mL}^{-1}$ for OML and $0.21 \mu \mathrm{g} \mathrm{mL}^{-1}$ for HCT limits of quantitation (LOQ) $1.32 \mu \mathrm{g} \mathrm{mL}^{-1}$ for OML and $0.63 \mu \mathrm{g} \mathrm{mL}^{-1}$ for HCT, which showed good precision for the proposed RP-LC method [26]. The proposed method was used for the determination of both drugs in tablets and results are shown in Table 2 indicating satisfactory recoveries and high precision.

\section{High Performance Thin Layer Chromatography}

A number of experimental parameters, such as mobile phase composition, scan modes and detection wavelengths, were optimized during method development in order to provide accurate, precise and reproducible results for the simultaneous determination of OML and HCT. Maximum separation (OML $R_{\mathrm{f}} 0.44$, HCT $R_{\mathrm{f}}$ 0.64 ) and minimum tailing were obtained when using a mobile phase composition of acetonitrile-ethyl acetateglacial acid $(7: 3: 0.5 v / v / v)$, respectively (Fig. 2).

Table 1 shows that correlation coefficients were 0.999 for OML and 0.994 for HCT. The LOD values were $20 \mathrm{ng}$ spot $^{-1}$ for OML and $19 \mathrm{ng} \operatorname{spot}^{-1}$ for HCT while LOQ values were 61 and $57 \mathrm{ng} \operatorname{spot}^{-1}$ for OML and HCT, respectively. The proposed method was used for the determination of both drugs in tablets and results are also shown in Table 2. Good recoveries and standard deviations were observed.

\section{Conclusion}

The selected methods were found to be sensitive, reproducible and accurate for the analysis of olmesartan medoxomil and hydrochlorothiazide in tablets. In general, both methods were found to be suitable for routine quality control analysis of the drugs in a combined tablet dosage form.

\section{Acknowledgments}

The authors express their gratitude to Ajanta Pharmaceutical Pvt. Ltd. (Paithan) and Glen mark Pharma Ltd. (Nashik) for providing gift samples of 
Table 2. Results of analysis of commercially available tablets containing olmesartan medoxomil and hydrochlorothiazide by RP-LC and HPTLC

\begin{tabular}{|llllll|}
\hline \multirow{2}{*}{ Method } & \multicolumn{2}{l}{ RP-LC } & & & \multicolumn{2}{l}{ HPTLC } & \\
\cline { 2 - 3 } & OLM & HCT & & OLM & HCT \\
\hline Labeled claim mg tablet & & & & \\
\% mean $(n=4)$ & 20 & 12.5 & & 20 & 12.5 \\
Standard deviation & 100.24 & 100.1 & & 100.09 & 99.77 \\
SE & 0.2926 & 0.3354 & & 1.3123 & 1.6030 \\
RSD $(\%)$ & 0.1462 & 0.1677 & & 0.6562 & 0.8015 \\
& 0.2919 & 0.3351 & & 1.3112 & 1.6067 \\
\hline
\end{tabular}

SE standard error

Track 2.10:

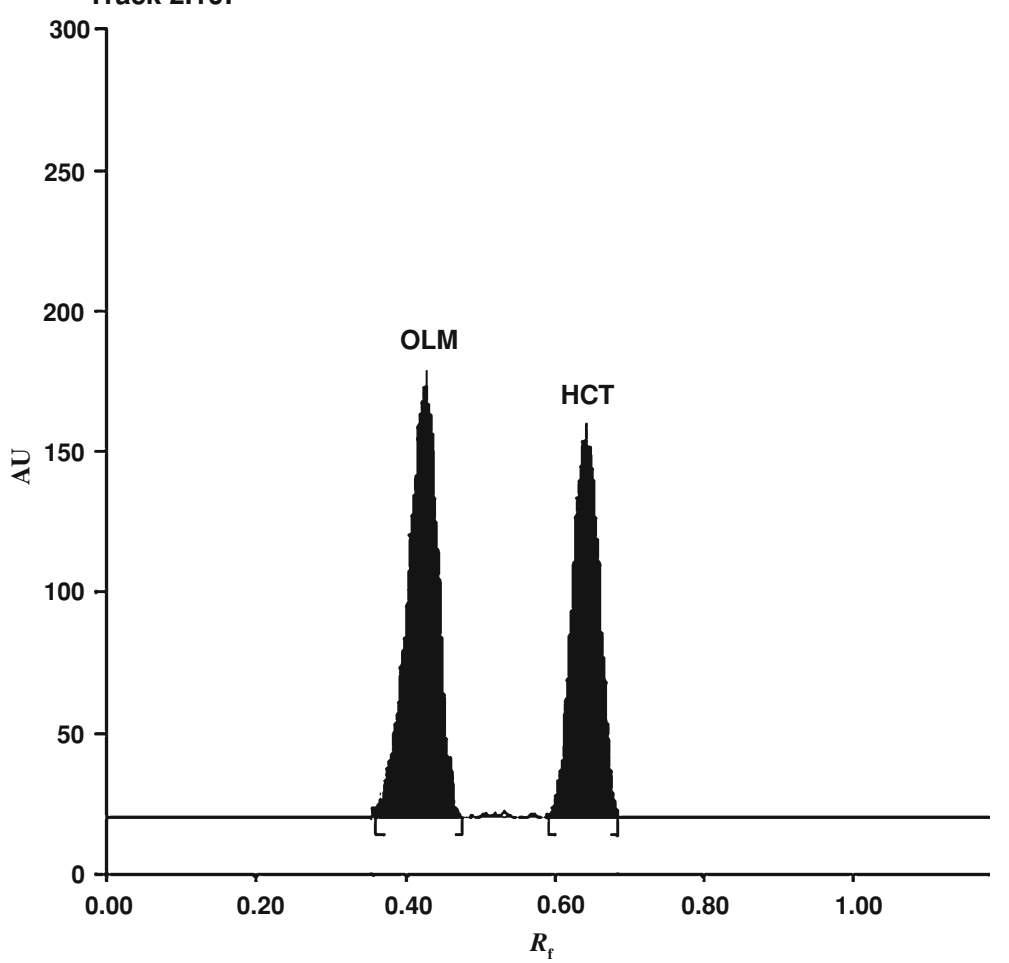

Fig. 2. Densitogram of olmesartan medoxomil (200 ng spot $\left.{ }^{-1}, R_{\mathrm{f}} 0.44\right)$ and hydrochlorothiazide (125 ng spot $\left.{ }^{-1}, R_{\mathrm{f}} 0.64\right)$

pure olmesartan medoxomil and hydrochlorothiazide, respectively. Thanks are also extended to Management and Principal, MGV's Pharmacy College for providing necessary facilities.

\section{Open Access}

This article is distributed under the terms of the Creative Commons Attribution Noncommercial License which permits any noncommercial use, distribution, and reproduction in any medium, provided the original author(s) and source are credited.

\section{References}

1. Koike H, Konse T, Sada T, Ikeda T, Hyogo S, Hinman D, Saito H, Yanagisawa H (2003) Annu Rep Snakyo Res Lab $55: 1-91$

2. Mire DE, Silfani TN, Pugsley MK (2005) J Cardiovasc Pharmacol 46:585-593. doi: 10.1097/01.fjc.0000180902.78230.fd
3. Kobayashi N, Fujimori I, Watanabe M, Ikeda T (2000) Anal Biochem 287:272278. doi:10.1006/abio.2000.4840

4. Yanagisawa H, Amemiya Y, Kanazaki T, Shimoji Y, Fujimoto K, Kitahara Y, Sada T, Mizuno M, Ikeda M, Miyamoto S, Furukawa Y, Koike H (1996) J Med Chem 39:323-338. doi:10.1021/jm950450f

5. Unger T, McInnes GT, Neutel JM, Bohm M (2004) Drugs 64:2731-2739. doi: 10.2165/00003495-200464240-00002

6. Reynolds JGF (ed) (1989) Martindale: the extra pharmacopoeia, 29th edn. The Pharmaceutical Press, London, pp 977-978

7. Dongyang L, Pei $\mathrm{H}$, Nobuko $\mathrm{M}$, Xiaoming L, Li L, Ji J (2007) J Chromatogr B 856:190-197. doi:10.1016/j.jchromb.2007. 05.049

8. Vaidya VV, Roy MN, Yetal SM, Joshi SS, Parekh SA (2008) Chromatographia 67:147-150. doi:10.1365/s10337-0070453-x

9. Mustafa C, Sacide A (2007) Chromatographia 66:929-933. doi:10.1365/s10337007-0424-2

10. Sagirli O, Onal A, Toker SE, Ensoy DS (2007) Chromatographia 66:213-218. doi: 10.1365/s10337-007-0304-9

11. Tomonori M, Hidetoshi K, Naoto F, Michinobu O, Takao K, Fumiyo K (2008) J Pharm Biomed Anal 47:553-559. doi:10.1016/j.jpba.2008.02.021

12. Shah NJ, Suhagia BN, Shah RR, Patel NM (2007) Ind J Pharm Sci 69:834-836. doi:10.4103/0250-474X.39447

13. British Pharmacopoeia (2001) Her Majesty Stationary Office, London, pp 2144 (II)

14. The United States Pharmacopoeia, NF (2003) pp 911 (24)

15. Farthing D, Fakhry I, Ripley E, Sica D (1998) J Pharm Biomed Anal 17:14551459. doi:10.1016/S0731-7085(98)00021-1

16. Martin ME, Hernandez OM, Jimenez AI, Arias JJ, Jimenez F (1999) Anal Chim Acta 381:247-256. doi:10.1016/S00032670(98)00732-6

17. Erk N, Onur F (1996) Anal Lett 29:19631974

18. Martin E, Hernandez O, Jimenez F, Arias JJ (1995) Anal Lett 28:1449-1464

19. Erk N (1999) J Pharm Anal 20:155-167. doi:10.1016/S0731-7085(99)00009-6

20. Panderi IE (1999) J Pharm Biomed Anal 21:257-265. doi:10.1016/S0731-7085(99) 00134-X

21. Erk N, Onur F (1997) Analysis 25:161-167

22. Ouyang J, Baeyens WRG, Delanghe J, Van Der Weken G, De Keukeleire D (1999) Anal Chim Acta 386:257-264. doi: 10.1016/S0003-2670(99)00020-3

23. Shetkar PB, Shinde VM (1997) Anal Lett 30:1143-1152

24. Erk N (2001) J Pharm Biomed Anal 24:603-611. doi:10.1016/S0731-7085(00) 00434-9

25. Gindy AE, Ashour A, Fattah LA, Shabana MM (2001) J Pharm Biomed Anal 25:171-179. doi:10.1016/S0731-7085 (00)00480-5

26. ICH Guideline for Industry (1996) Q2 $\mathrm{R} 1: 9$ 